\title{
School libraries in the Northern Cape Province - where do we stand?
}

\author{
Leon C de Vries',
}

Teachers' Centre, Private Bag X5022, Kimberley 8300

Idevries@tc.ncape.gov.za (Cape Department of Education)

\author{
Roelof van der Merwe ${ }^{2}$, \\ Department of Curriculum Studies, School of Education, University of the Free State, P.O. Box 339, \\ Bloemfontein 9300 \\ vdmerwer.HUM@mail.uovs.ac.za
}

\begin{abstract}
Received:24 ${ }^{\text {th }}$ August 2003
Revised: $4^{\text {th }}$ March 2004

The shortage of reading material and information resources in many South African schools, especially those in poor communities, is a problem that needs to be addressed. While there has been considerable progress with the implementation of an outcomes-based curriculum relying on a learner-centred, resource-based methodology, libraries are largely absent in disadvantaged schools. This paper reviews the situation of school libraries in the Northern Cape, highlighting progress made in the last few years. Lessons drawn from policy and implementation factors have implications for education planners, librarians and library educators.
\end{abstract}

\section{Introduction}

Many people from the world of libraries and information, and more especially the education sector, possibly will agree that school libraries are the Cinderellas of libraries. Although this may not only be a South African phenomenon, it does not set us free from our responsibility to provide a healthy, stimulating learning environment where books and other forms of information resources are an integral part of the learning experience. It is a challenge for schools preparing learners for a world where bombs and information are exploding.

An article in the second issue of South African Journal of Libraries and Information Science (Le Roux, 2002) drew attention to issues very relevant to school libraries and education. The supply of a wide variety of educational resources is regarded as a critical component of an outcomes-based curriculum. It is furthermore a great concern to the school library profession that a national school library policy does not exist in South Africa, because its absence has an adverse effect on the provision of school library services and curriculum reform initiatives (Le Roux 2002: II2). The question arises as to how much progress provinces have made, in the absence of a national school library policy, with the provisioning of school library services since 1994.

The focus of this article is on the school library situation in the Northern Cape Province. It describes the circumstances that the new Education Department of the province was confronted with in 1994 and the plans that were initially drafted to address the problems regarding school libraries, subsequent developments (also with regard to school funding) and the progress made until 2003. In conclusion the article looks at the way forward.

\section{Education in the Northern Cape after the 1994 election}

The Northern Cape Province came into being in 1994 as a result of the new democratic constitution of the country. The assets of the old Cape Province were divided between four new provinces, viz. the Northern Cape, Eastern Cape, Western Cape, and to a lesser degree the North West Province. For all practical purposes the Northern Cape had to structure a new Department of Education (De Vries, 2002: II). The Education Department established for the Northern Cape was part of the Department of Education, Training, Arts and Culture. This is of significance as it had an influence on the initial planning for school libraries in the province. It was very much a time of transition and transformation and consequently accompanied by much uncertainty and systemic problems.

The Northern Cape Province, as well as other provinces of the new South Africa, inherited a fragmented education system characterised by gross inequalities in the education facilities and the quality of education available to the different population groups. The schools of the Northern Cape Province were until 1994 either part of the Department of Education and Training (Blacks), the House of Representatives (Coloureds) or the House of Assembly (Whites) (Scott, 1995: 2).

I. Leon C de Vries works in the Teachers Centre, Northern Cape Department of Education, Kimberley, South Africa

2. Roelof van der Merwe is a Professor in the Department of Curriculum Studies, University of the Free State, South Africa 
A prominent feature of the Northern Cape school setup was the $17 \%$ of schools classified as farm schools. These schools catered for only 2,5\% of the learners of the province (Arnott \& Bergmann, 1997: 2). Many of the farm schools had an enrolment of about twenty learners, being taught by a single educator in a multi-grade classroom situation (Northern Cape Province. Ministry of Education, 1995: 7.2).

Another striking feature of the Northern Cape with consequences for education provision is the large percentage of poor people in the province. In 1994, 48\% of the population was living under the poverty line (Arnott \& Bergmann, 1997: 4).

From a school library perspective it is important to note that the Northern Cape Province was left without any school library advisers after the division of the assets of the Cape Province. Similarly, the province was left with no school library infrastructure apart from the school libraries in a minority of schools (Swartbooi, 1998: 3).

Although accurate statistics on the school library situation in the Northern Cape did not exist at that time, there was enough evidence from the observation and evidence of teachers that the situation in the province more or less reflected the South African situation. The findings of Overduin and De Wit (1986 and 1987) showed huge differences in the quality of the school library services of the various education departments. Whilst libraries of different quality could be found in Coloured schools, the situation in Black schools was desperate. Other reports and articles of circa 1990 confirmed the findings of Overduin and De Wit (see Braude, 1992; Stadler, 1992; Vermeulen, 1991; Zaaiman, 1998).

An important task of the Northern Cape provincial government was the structure of the province's education department because it had an influence on the planning for school libraries in the province. The Education Department or administration of the province was part of its Department of Education, Training, Arts and Culture that consisted of four directorates, viz. Provisioning and Development Services, Auxiliary Services, Arts and Culture and lastly, Administrative Services (Northern Cape Province. Ministry of Education, 1995: 3.1). The Provincial Library Service was part of the Directorate: Arts and Culture. Education and Provincial Library Services were consequently part of the same department.

The circumstances as described above were the background against which the Northern Cape Province had to start planning for its school libraries in 1994.

\section{Proposals for school libraries: views from non-governmental organisations}

In planning for school libraries, provinces could draw on various policy proposals and reports published or made available since 1990. After the lifting of the ban on the African National Congress (2 February 1990) it became apparent that South Africa was standing at the threshold of large scale political and social changes. On a wide front library and information workers and professionals were conferring on library and information provisioning for a new South Africa. In the process the question of library and information provisioning of schools was also raised. Amongst the documents are the NEPIreport (National Education Policy Investigation) of 1992, the TransLis-reports (Transforming our Library and Information Services) of 1994, the ANC's Policy Framework for Education and Training (1994), the IPET-document (Implementation Plan for Education and Training, 1994) mandated by the ANC and compiled by the Centre for Education Policy Development, as well as the LISDESA-document (Library and Information Services in Developing South Africa) of 1995.

Study and analysis of the above documents showed similarities; for instance, the need to have some kind of vision of where the school library system and access to information resources for learners and educators should be heading or objectives to fulfil, as well as principles for the provisioning of school library and information services. One of the key principles that formed part of the vision for the future was that a unitary library and information system (LIS) should be established for South Africa and that it should be integrated with the education system. Other principles included democracy, non-discrimination, redress, optimal utilisation of resources and the importance of information skills (National Education Coordinating Committee 1992: 3. African National Congress. Education Department 1994: 79-80, African National Congress. Education Department. Centre for Education Policy Development, 1994: 209, Transforming our Library and Information Services, 1994a: I, 4, 5 and 1994b: I, 3, Library and Information Services in Developing South Africa Conference 1995b: 23, 28-29).

A range of provisioning requirements was also identified, viz. the need for some kind of national school library policy and standards, legislation funding, provisioning and advisory structures, governance structures, strategies for the optimal utilisation of resources, the provisioning of library collections, staff and accommodation. There were also curriculum and training needs, e.g. the need for information skills to be an integral part of the curriculum and learning in all the different learning areas (De Vries 2002: 96-103).

The question arises to what extent the vision, principles and needs as identified in the documents of the nongovernmental organisations were addressed and reflected in the planning documents for school libraries of the Northern Cape Province. 


\section{The school library documents of the Northern Cape Province, 1994 - 1999}

The planning for school libraries in the Northern Cape started in 1994 while important national and provincial legislation for education still had to be promulgated. The White Paper on Education and Training was made available in 1995 and the National Education Policy Act, the South African Schools Act and the Northern Cape School Education Act followed in 1996.

Documents on school libraries for the Northern Cape that came to existence during the period 1994 to 1999 are the following:

- The Arts and Culture Task Group (ACTAG) for the Northern Cape made its ACTAG report available during 1995. It was a provincial edition of the national ACTAG report showing very little changes from the national document (Northern Cape Province. Northern Cape Arts and Culture Task Group 1995).

- An Education official, mandated by the Department of Education, and in consultation with library teachers was responsible for the drafting of a document with the title Education Media Services (Multi-Media Services) for the Province of the Northern Cape: A practical model (the EMS report) during 1994 and 1995 (Northern Cape Province. Department of Education 1995). This report included school libraries.

- During one of the consultative workshops in the drafting process of the EMS report the then acting head of the Provincial Library Service addressed the meeting on the possible role that the Provincial Library Service could play with regard to school libraries (Scholtz, 1995).

- In 1998 the Directorate of Arts and Culture released the Northern Cape Libraries Bill (Northern Cape Province. Directorate of Arts and Culture, 1998). Although this bill was never approved by the Provincial Legislature, it gives an indication of what the Provincial Library Service had in mind for school libraries.

- The last document from the period 1994 to 1999 was drafted by the Regional Librarian of the Kimberley Library Region (Swartbooi, 1998). It contained proposals with regard to a provincial school library service and was presented by him to the previous head of the Northern Cape Education Department.

Not one of the above documents could claim to be the official policy document of the Northern Cape Department of Education, Training, Arts and Culture. Nevertheless, these documents give an indication of the direction in which school library provisioning could have developed.

A document that is not really concerned with school libraries, but has implications especially for the provisioning thereof, is the Northern Cape School Education Act of 1996 (Northern Cape Province. Office of the Premier, 1996).

\section{The school library plans for the Northern Cape Province, 1994 - 1999}

\subsection{Vision and mission}

In considering the school library plans for the Northern Cape, the first question is what the ideal circumstances were that had been envisaged for the future, i.e. the drafters' vision for the future.

Three of the school library documents available did not include vision statements. However, the concise vision statement of the Regional Librarian of Kimberley encapsulates the gist of all the documents, viz. access to library material and media for all learners of the province (Swartbooi, 1998: 17). The school library service would have to ensure that this became a reality.

The ACTAG report for the province gave a more elaborate description of its school library vision. In order to support resourced-based learning, the report declared that every school should have access to appropriate curriculum-related information resources and facilities, whether in the school itself, shared with other schools or shared with the community. Facilities in schools should be backed by suitable professional and administrative services at district and provincial levels. There should also be a phased development plan to ensure that ultimately each school will have its own library or media centre which will be fully integrated in the school's curricular and extra-curricular programmes. It mentioned that close co-operation between public and school libraries will be necessary and that their activities should be co-ordinated at local and provincial levels. The vision of the ACTAG report of the Northern Cape for school libraries and access to information resources was identical to that of the national ACTAG report (Northern Cape Province. Northern Cape Arts and Culture Task Group 1995: 201; South Africa. Department of Arts, Culture, Science and Technology, 1995: 12).

In fulfilling the vision of access to information resources for all learners of the province the school library service has to execute its mission or 'prime' or 'basic function' (see Saville, 1994: 290; Eksteen, 1994: GI 2 for definitions of a 'mission').

Two of the Northern Cape documents include mission statements for the school library service in the province. The mission of the EMS document mentioned the promotion and support of information literacy in order to promote lifelong learning and to improve the quality of the life for the people of the province (Northern Cape Province: Department of Education, 1995: I). Three main functions are identified that should be undertaken by the Education Department, viz. 
media selection, media provisioning and maintenance and media advice (Northern Cape Province. Department of Education 1995: 3).

In Swartbooi's (1998: 4) mission statement a number of objectives for a school library service are identified. He called for the establishment of a school library programme that can serve as a vehicle to promote Curriculum 2005 and for the development of school libraries into vibrant learning centres. The school library should be an instructional tool available to teachers and learners in order to raise the quality of instruction and enable learners to become actively involved in the search for knowledge. By giving learners access to a variety of information sources critical thinking should be promoted. Learners should be enabled to acquire the necessary skills for lifelong learning and use new technology in meaningful situations.

\subsection{Principles}

The principles that are featured in the documents of the non-governmental organisations can also be found in the Northern Cape documents:

Unity

The Northern Cape ACTAG report subscribes to the principle of a unitary LIS system. This would require bringing together the fragmented system in a coherent fashion, making possible improved co-ordination and greater integration of the various components of the LIS system. '(It) ... would imply that present distinct library types such as public and school libraries could be combined to provide more appropriate services' (Northern Cape Province. Northern Cape Arts and Culture Task Group, 1995: 206).

\section{Democracy}

Public schools and school education will be governed democratically (Northern Cape Province. Office of the Premier, 1996: art. 4(I)(i)). The LIS system and all its components should be managed democratically. Users and staff must be empowered to participate in decision-making at grass-roots level concerning such matters as collection development and service policies (Northern Cape Province. Northern Cape Arts and Culture Task Group, 1995: 204).

\section{Redress}

The unequal provision of LIS in the Northern Cape necessitated the urgent need for redress by concentrating provision in impoverished regions such as rural areas, townships and informal settlements: 'Only in a small proportion of the schools serving the majority of the population is there an adequate provision of school library/media centre facilities' (Northern Cape Province. Northern Cape Arts and Culture Task Group, 1995: 205). There was a duty on the Education department 'to foster the advancement of persons or groups ... previously disadvantaged by unfair discrimination ...' (Northern Cape Province. Office of the Premier 1996: art. 4(I)(d)). The eradication of "backlogs in school library provisioning should be addressed in the provincial Education budget as a priority' (Swartbooi, 1998: 13).

\section{Non-discrimination}

All LIS agencies and personnel should be committed to non-discriminatory practices in respect of resource allocation, services to users and employment. LIS agencies should play a role in combating racism, sexism and other forms of discrimination, e.g. discrimination on grounds of mental or physical ability and religious beliefs (Northern Cape Province. Northern Cape Arts and Culture Task Group, 1995: 205). Every learner and educator shall have the right to freedom of conscience, religion, thought, belief, opinion, speech and expression and the education process shall promote a culture of tolerance (Northern Cape Province. Office of the Premier, 1996: art. 4(I)(f)). No learner or educator shall be unfairly discriminated against by the Education Department, public school or an independent school which receives a subsidy (Northern Cape Province. Office of the Premier, 1996: art. 4(I)(c)).

\section{Optimal utilisation of resources}

The EMS-document emphasises the 'effective utilisation of the present infrastructure' (Northern Cape Province. Department of Education, 1995: 2), whilst the Northern Cape School Education Act declares that 'Education policy shall be aimed at achieving cost efficient and effective use of educational resources, eliminating wastage, inefficiency, maladministration and corruption' (Northern Cape Province. Office of the Premier, 1996: art. 4(I)(i)).

\section{Information skills and information literacy}

The importance of information skills and information literacy is stressed in the Northern Cape documents. Education, for example, should strive to form independent learners by equipping them with the skills that will enable them to use a wide variety of sources (Northern Cape Province. Department of Education, 1995: 6). Information literacy should be an integral component of curricula in all phases of the lifelong learning process (Northern Cape Province. Northern Cape 
Arts and Culture Task Group, 1995: 219). 'To function properly certain skills and abilities are needed, such as the ability to interpret, assess, assimilate and disseminate information' (Swartbooi, 1998: 3).

\subsection{School library policy}

With regard to the need for a school library policy, the Northern Cape ACTAG report (based on the national ACTAG report) and the EMS report were both attempts to propose policy for school and community libraries in a new dispensation. New policies would have to be devised, implemented and refined over time (Northern Cape Province. Northern Cape Arts and Culture Task Group 1995: 5). The proposal of the Kimberley Regional Librarian also included the need to develop a written school library policy (Swartbooi, 1998: 19). Along with need for a school library policy the Northern Cape ACTAG report mentioned the necessity for provincial and national legislation to put in place a framework for library and information services (Northern Cape Province. Northern Cape Arts and Culture Task Group, 1995: 210, 23I). Indeed, the Directorate of Arts and Culture went ahead and released the Northern Cape Libraries Bill in 1998. It was, however, never approved by the Provincial Legislature and therefore did not become an act of the province (Northern Cape Province. Directorate of Arts and Culture, 1998).

\subsection{Funding}

The question of funding was also addressed in some of the documents. The Northern Cape ACTAG report declared that school and public libraries should be funded primarily by the provincial government. It would be the responsibility of the Department of Education, Training, Arts and Culture (Northern Cape Province. Northern Cape Arts and Culture Task Group, 1995: 219). The responsibility of the state to provide schools and education was acknowledged in the Northern Cape Education Act of 1996. It declared that 'the state shall fund schools from public revenue on an equitable basis ...' (Northern Cape Province. Office of the Premier, 1996: art. 50(I)). In addition, the governing body of a public school should 'take all reasonable measures within its means to supplement the resources supplied by the State in order to improve the quality of education provided by the school to all learners at the school' (Northern Cape Province. Office of the Premier, 1996: art. 50(3)). The possibility of funding through donors, including development agencies from abroad, was also suggested (Swartbooi, 1998: 7).

\subsection{Provisioning structure and governance}

The provisioning structure proposed for the Northern Cape was broadly based on the unity principle and the location of Education and Provincial Library Services in the same department. According to the Northern Cape ACTAG document such a grouping would favour close co-ordination of school and public library services. The Provincial Library Service could assist with the provisioning of books, media and software to schools, as well as the rebinding of books and stock control. The existing regional library infrastructure could be utilised for the purpose. Acquisitions and processing could be centralised to achieve economies of scale. The school library itself would then be supported by the Education authorities through a separate library advisory service within the Education Department (Northern Cape Province. Northern Cape Arts and Culture Task Group, 1995: 204, 221). The plans of the Department of Education, Training, Arts and Culture made provision for a Directorate: Arts and Culture with four sub-directorates, inter alia Library Services. The SubDirectorate: Library Services would have consisted of four units, one of which was Education Library Services (Scholtz, 1995: 5). The EMS document and the Regional Librarian also proposed that Provincial Library Service should take responsibility for school libraries and handle the provisioning of information sources. However, the Education Department would still have the responsibility to provide a school library advisory service (Northern Cape Province. Department of Education, 1995: 3, 5; Swartbooi, 1998: II).

In terms of governance the Northern Cape ACTAG report and the Northern Cape Libraries Bill proposed the establishment of a provincial LIS Council as well as advisory bodies on regional level. The Northern Cape ACTAG report also proposed the local advisory bodies. The LIS Council and the various advisory bodies would inter alia be responsible for the co-ordination of LIS activities in the province (Northern Cape Province. Northern Cape Arts and Culture Task Group, 1995: 212, 213) (Northern Cape Province. Directorate of Arts and Culture, 1998: art. 3(2)(a), (s) and art. $6(10)(c),(d))$.

\subsection{The optimal utilisation of resources}

Strategies that were proposed for the optimal utilisation of resources in the province are co-ordination, resource sharing and alternative library models. The Northern Cape ACTAG report declared that the Department of Education, Training, Arts and Culture should ensure that the public and school library systems are co-ordinated and that the latter are appropriately linked to a provincial resources sharing system (Northern Cape Province. Northern Cape Arts and Culture Task Group, 1995: 210). If both the public and education library services were put in the same department, such a grouping would favour close co-ordination of school and public library services (Northern Cape Province. Northern Cape Arts and Culture Task Group, 1995: 22I). In areas where schools did not have libraries, steps should be taken to 
encourage schools to make use of public libraries if available and not too distant. There should be co-ordination and cooperation between the school and the public library: schools should inform libraries well ahead of the date about the information sources that will be needed. Teachers and public librarians should have a good working relationship. Coordination and co-operation could be enhanced by formal meetings (Northern Cape Province. Northern Cape Arts and Culture Task Group, 1995: 222, Swartbooi, 1998: 15). It would be the function of a local LIS committee to co-ordinate the services of the public and school libraries (Northern Cape Province. Northern Cape Arts and Culture Task Group, 1995: 214).

The ACTAG report advocated the inclusion of school libraries in a resource sharing system and proposed some kind of subsidy to alleviate the burden of inter-lending loans on the budgets of institutions. Agencies outside the public sector should also be encouraged to share their resources. State subsidy could be used as an incentive for resource sharing. To facilitate resource sharing on all levels it was important to have a computerised provincial library information system (Northern Cape Province. Northern Cape Arts and Culture Task Group, 1995: 217). The forging of closer working relationships between schools and community libraries could contribute to the sharing of resources between them (Swartbooi, 1998: 19). Teachers in this regard should be encouraged to make use of block loans at the public library (Swartbooi, 1998: 15).

Resource sharing between schools in the same neighbourhood was another possibility. If schools were linked to an education database, it could assist resource sharing (Northern Cape Province. Northern Cape Arts and Culture Task Group, 1995: 220).

In order to further the optimal use of limited resources, alternative school library models were a possibility as well. The alternative model most frequently mentioned is the school community library. It would entail a joint project between the Provincial Department of Education, the Provincial Library Service and the local government structure or municipality. The advantage of the school community library is the elimination of the duplication of facilities and stock. The reason for this is that the available resources are pooled, making it possible to provide a bigger and better equipped and staffed library (Northern Cape Province. Department of Education, 1995: 7; Northern Cape Province. Northern Cape Arts and Culture Task Group, 1995: 220, Swartbooi, 1998: 13).

\subsection{Collection development}

The reality is that many schools still do not have library collections. To address this problem it was proposed that core collections of basic information resources could be provided (Northern Cape Province. Department of Education, 1995: 7; Swartbooi, 1998: 13). The possibility that a non-governmental organisation with much experience in this field, the READ Educational Trust, could assist, was also mentioned (Northern Cape Province. Department of Education, 1995: 7).

An important aspect of collection development is the selection of appropriate material. This is one aspect of library services that lends itself to co-operation between the different provinces. Provinces could, with mutual consent, make use of each other's selection lists (Northern Cape Province. Department of Education, 1995: 3).

With regard to the procurement and the distribution of library material it was mentioned that various documents suggested the possibility that the Provincial Library Service could take on this responsibility (see 5.5). However, in order to ensure that the needs of the schools and the curriculum are taken into account, consultation between the Education Department, library educators and the Provincial Library Service would be necessary (Northern Cape Province. Department of Education, 1995: 4; Swartbooi, 1998: 17).

\subsection{Staff and accommodation}

Documents from the Northern Cape further emphasised the necessity of adequate staff levels for the school library. It is regarded as an essential requirement for the proper functioning of the school library (see Northern Cape Province. Department of Education 1995: 8; Northern Cape Province. Northern Cape Arts and Culture Task Group, 1995: 220, Swartbooi, 1998: 17).

Accommodation per se received very little attention in the documents. Nevertheless it was generally accepted and supported by the available data (as indicated in section 2) that especially black schools did not have accommodation for school libraries. Where they did exist they were used as additional classrooms to alleviate the problem of over crowded classrooms. The proposed school community library was seen as something that could contribute to alleviate the problem of accommodation for school libraries.

\subsection{Curriculum needs}

The last aspect, curriculum and training needs, concerned the utilisation of the library as an educational tool. The school library as part of the school's curriculum should assist learners to acquire information skills. Information skills should also be an integral part of subject teaching (Northern Cape Province. Department of Education, 1995: 6). Training should therefore not only cover the management of the school library, but also curricular aspects (Swartbooi, 1998: 14). 
In summary, the school library plans of the Northern Cape, to a large extent, were based on the assumption that the future development of school libraries would be the responsibility of the Provincial Library Service. The Education Department of the province did not have an infrastructure to support school libraries, and because both Education and the Provincial Library Service were part of the same department, it was seen as the solution for the problem. However, after the 1999 elections a new departmental structure was established. Since then Education and the Provincial Library Service are no longer part of the same department, and school libraries once more became the responsibility of the Education Department.

\section{The development of school libraries in the Northern Cape Province}

The period 1994 to 1999 was a time of planning while new departmental structures were taking form. The Northern Cape Education Department was left without any personnel responsible for the development of school libraries in 1994, and the Provincial Library Service that was supposed to be responsible for school libraries did not have the financial and human resources to give much attention to the school library situation. Statistics reflecting the situation were published in the School Register of Needs reports of 1996 and 2000.

The 1996 report found that $33 \%$ of schools in the Northern Cape ( 175 of 526 public and independent schools) had libraries. Although this was a very unsatisfactory situation, the Northern Cape was in the third best position compared to the other provinces. For South Africa as a whole only 17\% of schools (4638 of 27/88) indicated that they had libraries (Bot, 1997: 3). During the four years since 1996 the number of schools in the Northern Cape decreased to 482. However the number of schools with libraries stayed the same, viz. 175 or $36,6 \%$ of the schools in the Northern Cape. Nationally the position also improved to 19,8\% (an improvement of 3\%) (South Africa. Department of Education, 2000: 39).

Although the above statistics do not reflect the quality and the utilisation of the school libraries and collections available, it is obvious that much remains to be done. Some progress has been made with the assistance of donor funding. The United States Agency for International Development (USAID) sponsored the establishment of nine resource centres at rural schools in the Kimberley District (Academy for Educational Development and the Education Foundation Trust 200I: par. 2; Northern Cape Province. Department of Education 200I: par. 5). The facilities of the resource centres were also made available to schools in the vicinity of each resource centre (Northern Cape Province. Department of Education, 200I: par. 7).

USAID also sponsored a project to provide 153 disadvantaged schools, mostly very poor farm schools, with box libraries in order to make library books more readily available to learners far from library facilities. The schools received in total 1094 box libraries from the supplier, READ Educational Trust. Each box has 50 fiction and 50 non-fiction titles. As part of the project READ has to provide training in the effective utilisation of the material (three courses) to 600 educators over a period of two years (READ Educational Trust, [200la]: 2, 3; READ Educational Trust, [200 Ib]: 4.5 \& 4.8).

More progress has also been made through a project, sponsored by the Swedish International Development Agency (SIDA) and completed in 2002, whereby 100 schools in disadvantaged communities received mobile library cabinets or book wagons (a cabinet on wheels). Each has a stock of 210 books and can be moved from one classroom to the other. As in the case of the box libraries, the supplier had to train teachers from recipient schools in the utilisation of the books for curricular purposes (Kiva, 2002).

A few schools also received book wagons from the Provincial Library Service sponsored by a 200 I grant from the Carnegie Corporation in New York (Vallabh, 2002).

The most recent statistics reflecting the school library situation from a provisioning perspective are based on the 2002 survey of the Northern Cape Department of Education. In this survey II 4 of the 440 public schools $(25,9 \%)$ indicated that they have a functionally built library or media centre. Seventy schools $(16 \%)$ indicated that did not have a library, media centre or library collection. One hundred and fourteen schools indicated that they did not have a library, media centre or library collection. A large number, namely 256 (58,2\%), have some form of classroom collection or room utilised as a library (Northern Cape Province. Department of Education. Sub-Directorate Policy and Planning, 2002).

The above statistics, however, do not give information on the quality and size of the library collections, nor on the utilisation of facilities where they exist.

\section{Funding of schools}

A factor that may have an influence on the future development of school libraries is the funding of schools. The funding of poor schools has improved considerably since the 2000 (January to December) financial year, because of the National Norms and Standards for the Funding of Schools (promulgated in 1998) which became effective in 1999. The Northern 
Cape, like other provinces, had to plan and implement the National Norms and Standards for the Funding of Schools during 1999. The Norms and Standards referred to the fact that the South African Schools Act of 1996 'imposes a responsibility on all public school governing bodies to do their utmost to improve the quality of education in their schools by raising additional resources to supplement those which the state provides from public funds' (South Africa. Department of Education, 1998: section 45). This funding provision worked in favour of public schools supported by middle-class and wealthy parents, and it enabled them to add to their facilities, equipment and learning resources (South Africa. Department of Education, 1998: section 46). Consequently the gap between affluent schools and the disadvantaged schools was not really reduced. The Norms and Standards also draws attention to the reality that poor people have to contribute a disproportionate share of their income to the education of their children (South Africa. Department of Education, 1998: section 47).

In the light of the above, the Norms and Standards for the Funding of Schools stated that the construction of new schools and additional classrooms and learning facilities should target the neediest sectors of the population (South Africa. Department of Education, 1998: section 91). The same principle applies to recurrent costs: 'Allocations ... must be cargeted as far as possible on the basis of need, determined according to the condition of the school and the relative poverty of the school community' (South Africa. Department of Education, 1998: section 99). Each Provincial Education Department is required to produce a list of schools in its province, sorted according to the conditions at the school and the poverty of the community served by the school, in order to produce five groups of schools, sorted 'from poorest to least poor'. The allocation of resources is based on the list (South Africa. Department of Education, 1998: section 100). The poorest $20 \%$ of the schools will receive $35 \%$ of the resources, the following $20 \%$ will receive $25 \%$, the following $20 \%$ will receive $20 \%$, the following $20 \%$ will receive $15 \%$ and the final $20 \%$ will receive $5 \%$ (South Africa. Department of Education, 1998: figure 2).

Section 2 I of the South African Schools Act (1996) determined that a school governing body (SGB) can apply to be allocated, inter alia, the function to maintain and improve the school's property and buildings and to purchase textbooks, educational material or equipment for the school (South Africa. Department of Education, 1996: section 21). A school with section 2 I functions receives a lump sum per learner transferred for the payments for which it has the responsibility according to its poverty ranking. From a school library provisioning perspective the following sentence is important: 'In general, ... SGBs may vary the proportion of funding devoted to such goods and services according to their own perception of education needs ...' (South Africa. Department of Education, 1998: section 109). Section 21 schools may deal directly with suppliers and contractors for the procurement of the necessary goods and services. Schools without section 21 functions receive their budgets on paper and have to procure through the administrative channels of the Education Department (South Africa. Department of Education, 1998: section II I).

The crux of the matter is that the SGB can thus decide to budget for school library development or to move it down on its priority list.

The Norms and Standards for the Funding of Schools identified different categories of recurrent costs to be funded according to the poverty ranking of the school, but in the case of learning materials (books and stationery) it determined that all learners must be provided with a minimum package equivalent to at least RI00 per learner. If the budget of the Provincial Education Department is not sufficient to cover this item, priority is given to schools highest in the poverty rank order (South Africa. Department of Education, 1998: section 117). The amount must increase annually to make provision for inflation (South Africa. Department of Education, 1998: section II8).

The new funding regulations have made it possible for the Northern Cape to increase considerably its subsidy to schools that were lacking in resources. The Northern Cape used its poverty ranking list as a sliding scale in such a way that no two schools received the same per learner allocation. On average the per learner allocation for the poorest $20 \%$ of schools was R380 in the 2000 financial year. The per learner allocation for the $20 \%$ of the least poor schools (or the 20\% lowest on the poverty ranking) was Rand I 55 (Education Foundation, 2000: 35).

Although the Norms and Standards ensure that more money is allocated to poor schools, it does not ensure that some of it is utilised for the development of the school's library. This applies to poor and more affluent schools. However, in the case of the latter there is a better chance that the school may find some money for library material.

\section{Conclusions}

The Northern Cape has made some progress notwithstanding enormous challenges and obstacles that the province had to face after 1994. Not only had the province to form a new Department of Education, Training, Arts and Culture, but most of the planning for school libraries could not be implemented because of changes in departmental structures after the 1999 elections. While it was initially envisaged that the Provincial Library Service would be responsible for the 
provisioning of library material to school libraries once its staff component and budget had been strengthened, it became the responsibility of the Northern Cape Department of Education after the restructuring of 1999.

In spite of the absence of a specific infrastructure and staff to support school libraries, some progress has been made. It is reflected in the number of schools that have received library books in the form of box libraries or the book wagons that are moveable from one classroom to the other. A very welcome aspect of the contracts with the suppliers was the stipulation that they had to provide training to educators in the utilisation of the library material for curriculum purposes.

However, for the time being schools are to a large extent dependent on their own initiative to develop school libraries. At this stage the Education Department has a resource centre with two staff members in Kimberley and an official responsible for the development of school libraries, as well as a resource centre in one of the four districts of the province.

A very positive development is the way in which funding for needy schools has been increased. A negative feature is that schools, especially those in very poor communities, may find it difficult to budget for the school library because of the many needs of schools and the priorities of the school governing bodies. Another worrying aspect is the lack of trained staff for the school library and, consequently, the under-utilisation of the libraries where schools are fortunate enough to have these facilities.

The absence of a national approved school library policy or national approved guidelines for school libraries is also a factor negatively effecting school library development.

Some implications of the situation in the Northern Cape are the following:

- The province should embark on a strategy to develop an Education Library and Information Service (ELIS) consisting initially of an Education Library and a school library adviser for each of the four districts of this vast province. This is something that was left undone because in the original planning school libraries were the responsibility of the Provincial Library Service and, especially after 1999, because of all the demands on the budget of the province that was still in the process to build a new Education Department.

- School library advisers should be able to advise library teachers, not only on the management of the library, but also on the development of information skills as part of the teaching of the different learning areas/subjects because information skills comprise one of the critical outcomes of Curriculum 2005 and are important for successful participation in an economy driven by information.

- The ELIS should develop a school library policy for the province based on a national school library policy or national school library guidelines as soon as it becomes available. If necessary the province could go ahead and develop a policy based on principles such as democracy, redress, non-discrimination, optimal utilisation of resources and the importance of information skills and information literacy. The policy could then be adapted when national policy or guidelines are approved. Aspects that should receive attention in the provincial document are vision and mission statements, funding and budgets, services, governing and advisory structures, optimal utilisation of resources, library collections, staff and accommodation.

In the implementation process some of the aspects that need attention are the following:

- Schools will have to be encouraged through circulars and training and information sessions to budget for the development of libraries.

- Many teachers responsible for the school library are not trained librarians and much in-service training is needed to assist them with the management of the library and the development of the library collection.

- Schools will also have to ensure that the library teacher is assisted by a support structure or structures. The principal for example should be a member of a school library committee.

- A library will have to form part of the planning for all new schools. If practical, especially in the small rural communities, it could take the form of a school community library.

Other aspects that will have to be considered are inter alia the establishment of a computerised library network to facilitate resource sharing through inter-lending, improved co-operation with community libraries and the possibility of partnerships with the Provincial Library Service, e.g. library depots at farm schools open to community members. This will enable much neglected farm communities and workers to have access more readily to reading material.

The Northern Cape has made much progress during the last nine years, from a newly formed province with basically no departmental structure to a province with a fully-fledged Education Department with structures to fulfil most functions. With regard to school libraries and access to information resources for learners, there are still challenges that lay ahead.

The question that arises is 'What was planned for school libraries in the other provinces of South Africa after 1994, what was implemented and how much progress has been made?' 


\section{References}

Academy for Education Development and the Education Foundation Trust. 200I. Educator Resource Centre Training: Province: Northern Cape: 3 September 200I. [S.I.]: Academy for Education Development and the Education Foundation Trust.

African National Congress. Education Department. 1994. A Policy Framework for Education and Training. Braamfontein: African National Congress.

African National Congress. Education Department. Centre for Education Policy Development. 1994. Implementation Plan for Education and Training. [S.I.]: African National Congress.

Arnott, A. \& Bergmann, R. 1997. The Northern Cape Province's Contextual Realities Report. [S.I.]: Education Foundation.

Bot, M. 1997. School register of needs: A provincial comparison of school facilities, 1996. Edusource, 17: I-4.

Braude, S. 1992. The School Library in Contemporary South Africa. Staffrider, I0(4): 83-88.

De Vries, L.C. 2002. Die beskikbaarheid, voorsiening en benutting van skoolbiblioteekfasiliteite binne ' $n$ uitkomsgebaseerde onderwysbedeling in die Noord-Kaap Provinsie. M.Ed.-verhandeling, Universiteit van die Oranje-Vrystaat, Bloemfontein.

Education Foundation. 2000. Provincial procedures to produce and implement a resource targeting list - 2000. [S.I.]: Education Foundation.

Eksteen, F.R.L.N. 1994. Business Management: An Introduction. Cape Town: Nasou.

Kiva, S., a curriculum official of the Northern Cape Education Department. 2002. Personal interview. 17 July, Kimberley.

Le Roux, S. 2002. School library policy in South Africa: where do we satnd? South African Journal of Libraries and Information Science, 68(2): I1 $12-122$.

Library and Information Services in Developing South Africa Conference: A joint ALASA/SAILIS initiative (Durban). 1995a. Lisdesa proceedings: Part I. Durban: University of Natal.

Library and Information Services in Developing South Africa Conference: A joint ALASA/SAILIS initiative (Durban). 1995b. Lisdesa proceedings: Part II. Durban: University of Natal.

National Education Co-ordinating Committee. 1992. Library and Information Services: Report of the NEPI Library and Information Services Research Group. Cape Town: Oxford University Press.

Northern Cape Province. Department of Education. 1995. Education Media Services (Multi-Media Services) for the Province of the Northern Cape: A practical model. 16 February. Kimberley: Department of Education.

Northern Cape Province. Department of Education. 200I. Minutes: DDSP Resource Centre Meeting: 27 July 200I. Kimberley: Department of Education.

Northern Cape Province. Department of Education. Policy and Planning Sub-Directorate. 2002. Statistics based on the annual survey. Kimberley: Department of Education.

Northern Cape Province. Directorate of Arts and Culture. 1998. Northern Cape Libraries Bill. Kimberley: Directorate of Arts and Culture.

Northern Cape Province. Ministry of Education. 1995. Draft: Provincial Policy Document (Green Paper) on Education and Training in the Northern Cape Province. Kimberley: Ministry of Education.

Northern Cape Province. Northern Cape Arts and Culture Task Group. 1995. Report of the Northern Cape Arts and Culture Task Group presented to the Minister of Education, Arts and Culture, October 1995. Kimberley: Northern Cape Arts and Culture Task Group.

Northern Cape Province. Office of the Premier. 1996. Northern Cape School Education Act, No. 6 of 1996. Provincial Gazette Extraordinary 3(187): I-56.

Overduin, P.G.J. \& De Wit, N. 1986. Skoolbiblioteekwese in Suid-Afrika: 'n Kritiese evaluering. Bloemfontein: Universiteit van die Oranje-Vrystaat.

Overduin, P.G.J. \& De Wit, N. 1987. School librarianship in South Africa today. South African Journal of Library and Information Science, 55(3): $172-178$.

READ Educational Trust. [200 la]. USAID DDSP Box Library Project: Memorandum. Kimberley: READ Educational Trust.

READ Educational Trust. [200 l b]. USAID DDSP Box Library Project: Minutes of the meeting held at the N. Cape Department of Education on Friday, 04 May. [Kimberley]: [READ Educational Trust].

Saville, J.W. 1994. Business Studies II. Melbourne: Macmillan Education Australia.

Scholtz, D. 1995. Die moontlike rol van die Noord-Kaapse Provinsiale Biblioteekdiens ten opsigte van Skoolmediasentrums. Kimberley: Provinsiale Biblioteekdiens.

Scott, D. 1995. An Overview of Education in the Northern Cape. Durban: Education Foundation.

South Africa. Department of Arts, Culture, Science and Technology. 1995. Report on Libraries and Information Services. Pretoria: State Library.

South Africa. Department of Education. 1996. South African Schools Act, Act no. 84 of 1996. Government Gazette, 377(|7579): |-5|.

South Africa. Department of Education. 1998. National norms and standards for school funding. Government Gazette, 400(19347): I-37.

South Africa. Department of Education. 2000. Report on the School Register of Needs 2000 Survey. Pretoria: Department of Education.

Stadler, C. 1992. Rural School-Library Provision - Gross Inequalities. Matlhasedi, Dec.: 44-46.

Swartbooi, A. 1998. Proposal to introduce a school library service to the Northern Cape Province. Kimberley: Department of Education, Training, Arts and Culture.

Transforming our Library and Information Services. 1994a. School Library Policy Discussion Group (Natal): Draft Discussion Document. Supplement to Media Focus, 6(I), June 1994.

Transforming our Library and Information Services. 1994b. Southern Transvaal Region: National School Library Policy (Seventh Draft). Supplement to Media Focus, 6(I), June 1994. 
Transforming our Library and Information Services. 1994c. TransLis Forum: Draft founding agreement. Founding agreement of the TransLis Forum. [S.I.]: TransLis.

Vallabh, S., Head of the Northern Cape Provincial Library Service. 2002. Personal interview. 22 July, Kimberley.

Vermeulen, W.M. 199I. South African school libraries and standards. South African Journal for Library and Information Science, 59(2): $148-153$.

Zaaiman, R.B., Roux, P.J.A. \& Rykheer, J.H. 1988. The use of libraries for the development of South Africa. Final report on an investigation for the South African Institute for Librarianship and Information Science. Pretoria : University of South Africa. 